\title{
BISNIS MULTI LEVEL MARKETING PADA PT. K-LINK NUSANTARA DI TINJAU DARI HUKUM BISNIS ISLAM
}

\author{
Siti Nurhasanah ${ }^{1}$, Sulamat Taufik ${ }^{2}$ \\ ${ }^{1}$ Fakultas Agama Islam Universitas Azzahra \\ Email : ilmimuthia15@gmail.com \\ ${ }^{2}$ Fakultas Agama Islam Universitas Azzahra \\ Email : sulamattaufik@gmail.com
}

\begin{abstract}
The purpose of this research is to discuss the multi level marketing (MLM) business in terms of Islamic business law, as well as to find out how the business practices carried out by PT. K-LINK and whether K-Link's MLM business practices are in accordance with the DSN-MUI fatwa No 75 / DSN-MUI / VII / 2009. This study used descriptive qualitative method. The data collection techniques used interviews and documentation. Based on the research results it is known that the Multi Level Marketing business practices at PT. K-Link Nusantara, starting from its direct selling practice, marketing and recruiting, bonus distribution and prices have followed the existing Islamic law rules and can be said to be in accordance with the basic principles of the Islamic religion which refers to the Al-Quran, Hadith, and Ijma '. And the MLM business practices of PT. K-Link Nusantara is protected from something that is forbidden such as maisir, ghoror, haram, usury, indecency, dzulm and immorality. The aqad uses aqad al-bai '/ murabahah, aqad wakalah, aqad ju'alah, and aqad ujroh. All of these aqads are adjusted to the contents of the DSN-MUI fatwa Number 75 / DSN-MUI / VII / 2009 concerning the Guidelines for Direct Selling in Sharia Level, so the practice can be said to be in accordance with the DSN-MUI fatwa Number 75 / DSN-MUI / VII / 2009.
\end{abstract}

Keywords : Islamic Business Law, Multi Level Marketing, DSNMUI 
Abstrak: Penelitian ini bertujuan untuk membahas bisnis multi level marketing (MLM) di tinjau dari hokum bisnis Islam, sekaligus untuk mengetahui bagaimana praktik bisnis yang dilakukan oleh PT. K-LINK dan apakah praktek bisnis MLM K-Link sudah sesuai dengan fatwa DSN-MUI No 75/DSN-MUI/VII/2009. Penelitian ini menggunakan metode deskriptif kualitatif. Adapun teknik pengumpulan data menggunakan wawancara dan dokumentasi. Berdasarkan hasil penelitian diketahui bahwa praktik bisnis Multi Level Marketing pada PT. K-Link Nusantara mulai dari praktik dirrect sellingnya, pemasaran dan prekrutannya, sampai pada cara pembagian bonus dan harganya sudah mengikuti aturan hukum Islam yang ada dan sudah bisa dikatakan sesuai dengan prinsip dasar agama islam yang mengacu pada Al-Qur'an, Hadits, dan Ijma'. Dan praktik bisnis MLM PT. K-Link Nusantara terhindar dari sesuatu yang diharamkan seperti maisir, ghoror, haram, riba, bathil, dzulm dan maksiat. Aqadnya menggunakan aqad albai'/murabahah, aqad wakalah, aqad ju'alah, dan aqad ujroh. Semua aqad tersebut disesuaikan dengan isi fatwa DSN-MUI Nomor 75/DSN-MUI/VII/2009 Tentang Pedoman Penjualan Langsung Berjenjang Syariah, maka praktik nya sudah bisa dikatakan sesuai dengan fatwa DSN-MUI Nomor 75/DSNMUI/VII/2009.

Kata kunci : Hukum Bisnis Islam, Multi Level Marketing, DSNMUI; 


\section{PENDAHULUAN}

Memasuki zaman yang semakin modern seperti sekarang ini, banyak perkembangan yang terjadi di Indonesia, seperti berkembangnya teknologi, pendidikan, budaya, politik, ekonomi dan sebagainya. Khususnya pada perkembangan kegiatan ekonomi mengalami kemajuan pesat dan mayoritas masyarakat dalam kehidupan sehari-hari tidak dapat lepas dari kegiatan ekonomi tersebut. Dalam hal ini misalnya pemasaran suatu perusahaan berupa produk maupun jasa.

Sistem yang digunakan oleh suatu perusahaan dengan perusahaan lainnya juga berbeda-beda. Biasanya sistem yang digunakan dalam pemasaran suatu produk maupun jasa yaitu menggunakan sistem direct selling (penjualan langsung), sistem ini terbagi menjadi dua macam, yaitu sistem single level marketing (pemasara satu tingkat) dan sistem muti level marketing (pemasaran berjenjang).

Multilevel Marketing atau yang terkadang juga disebut dengan Networking Selling (jaringan penjualan) atau direct selling (penjualan langsung) adalah bentuk pemasaran suatu produk atau jasa dari suatu perusahaan yang dilakukan secara perorangan atau berkelompok yang membentuk jaringan secara berjenjang, lalu dari hasil penjualan pribadi dan jaringan tersebut, setiap bulannya perusahaan akan memperhitungkan bonus atau komisi sebagai hasil usahanya. (Peter J. Cloither, 1994)

Sedangkan menurut Harefa (2007) dalam sudut pandang yang sama menyatakan bahwa, MLM merupakan salah satu dari berbagai macam cara yang dapat dipilih oleh sebuahperusahaan atau pabrikan (produsen), untuk memasarkan atau mendistribusikan/ menjual produknya kepada pelanggan eceran, dengan memberdayakan distributor independennya untuk melaksanakan tugas penjualan produk melalui pengembangan penjual langsung secara mandiri, tanpa campur tangan langsung dari perusahaan

Multilevel Marketing adalah merupakan sebuah sistem pemasaran modern melalui jaringan distribusi yang dibangun secara permanen dengan memposisikan pelangganperusahaan sekaligus sebagai tenaga pemasaran. Singkatnya, bahwa Multilevel Marketing adalah suatu konsep penyaluran (distribusi) barang berupa produk dan jasa tertentu, yang memberi kesempatan kepada para konsumen untuk turut terlibat sebagai penjual dan memperoleh keuntungan di dalam garis kemitraannya. (Agustino, 2002)

Konsep perusahaan ini adalah penyaluran barang (produk dan jasa tertentu) yang memberi kesempatan kepada para konsumen untuk turut terlibatsebagai penjual dan memperoleh manfaat dan keuntungan di dalam garis kemitraannya. Dalam istilah MLM, anggota dapat pula disebut sebagai distributor atau mitra kerja. Jika mitra niaga mengajak orang lain untukmenjadi anggota sehigga jaringan pelanggan atau pasar semakin besar danluas itu artinya mitra niaga telah berjasa mengangkat omset perusahaan.Atas dasar 
inilah kemudian perusahaan berterimakasih dengan bentukmemberi sebagian keuntungannya kepada mitra niaga yang berjasa dalambentuk insentif berupa bonus, baik bonus bulanan, tahunan, ataupun lainnya.

Multi Level Marketing adalah menjual atau memasarkan langsung suatu produk baik berupa barang atau jasa konsumen, sehingga biaya distribusi dari barang yang dijual atau dipasarkan tersebut sangat minim bahkan sampai ke titik nol yang artinya bahwa dalam bisnis MLM ini tidak diperlukan biaya distribusi. MLM juga menghilangkan biaya promosi dari barang yang hendak dijual karenadistribusi dan promosi ditangani langsung oleh distributor dengan sistem berjenjang (Harefa, 2002).

Mekanisme operasional pada MLM ini adalah seorang distributor dapat mengajakorang lain untuk ikut juga sebagai distributor. Kemudian orang lain itu dapat mengajak pula orang lain lagi untuk ikut bergabung. Begitu seterusnya, semua yang diajak dan ikut merupakan suatu kelompok distributor yang bebas mengajak orang lain lagi sampailevel yang tanpa batas. Inilah salah satu perbedaan MLM dengan pendistribusian secara konvensional yang bersifat single level. Pada pendistribusian konvensional, seorang agen mengajak beberapa orang bergabung ke dalam kelompoknya menjadi penjual atau sales atau wiraniaga. Pada sistem single level para wiraniaga tersebut meskipun mengajak temannya, hanya sekedar pemberi referensi yang secara organisasi tidak di bawah koordinasinya melainkan terlepas. Mereka berada sejajar sama-sama sebagai distributor.

Multi Level Marketing (MLM) merupakan salah satu macam dari direct selling (penjualan langsung), dimana melakukan penjualan barang atau jasa tertentu kepada para konsumen melalui jaringan bisnis yang telah dibentuk oleh para distributor dengan cara tatapmuka dan memasarkan secara langsung. Pada awal zaman perkembangan Islam, bisnis MLM tentu belum ada. Karenanya, banyak orang berpendapat mengenai hukum MLM ada yang menghalalkan dan ada pula yang mengharamkan secara keseluruhan. Pendapat ini mengatakan bahwa MLM ada yang halal dan ada yang haram tergantung kepada sistem yang diterapkan dalam MLM tersebut.

Bisnis yang dijalankan dengan sistem MLM tidak hanya sekedar menjalankan penjualan produk barang, tetapi juga jasa, yaitu jasa marketing yang berlevel-level (bertingkat-tingkat) dengan imbalan berupa marketing fee, bonus, hadiah dan sebagainya, tergantung prestasi, dan level seorang anggota. Jasa marketing yang bertindak sebagai perantara antara produsen dan konsumen. Dalam istilah fikih Islamhal ini disebut Samsarah / Simsar. (Sayyid Sabiq, Fikih Sunnah, jilid II:159) Kegiatan samsarah dalam bentuk distributor, agen, member atau mitra niaga dalam fikih Islamtermasuk dalam akad ijarah. yaitu suatu transaksi memanfaatkan jasa orang lain dengan imbalan, insentif atau bonus(ujrah) Semua ulama membolehkan akad seperti ini (Fikih Sunnah, II, hlm.159). 
Akhir-akhir ini, perkembangan bisnis MLM diramaikan pula oleh hadirnya MLM berlabel Syari'ah. Keberadaan MLM Syari'ah di tanah air Indonesia menjadi penting artinya, mengingat mayoritas jumlah penduduk negara kita adalah muslim. Bagi kalangan muslim, mereka akan lebih cenderung memilih untuk melakukan kegiatan bisnis yang sesuai dengan mu'amalah Islam. Di tambah lagi kesadaran kaum Muslimin untuk mengembangkan ekonomi syari'ah semakin meningkat.

Multilevel Marketing (MLM) Syariah adalah sebuah usaha MLM yang mendasarkan system operasionalnya pada prinsi-prinsip syariah. Dengan demikian, system bisnis MLM Konvensional yang berkembang pesat saat ini dicuci, dimodifikasi dan dsesuaikan dengan prinsip syariah. Hal-hal yang diharamkan dan bersifat syubhat dihilangkan dan diganti dengan nilai-nilai ekonomi syariah yang berlandaskan tauhid, akhlak, hukum muamalah. (Kuswara, 2005). Menurut Ustadz Hilman Rosyad Syihab, Lc dalam tulisannya di majalah Network Bussiness dengan judul Multilevel Marketing, dijelaskan bahwa bisnis MLM yang sesuai syariah adalah MLM untuk produk yang halal dan manfaat dan proses pendistribusian atau cara berdagangnya tidak bertentangan dengan syariah, tidak dengan pemaksaan, penipuan, riba, sumpah yang berlebihan, pengurangan imbangan dan lainnya.

Selanjutnya Agustianto menjelaskan bahwa Multi Level Marketing (MLM) konvensional tentulah belum bisa disebut syariah, kecuali lolos sekian syarat kesyariahan. Berikut adalah ketentuan DSN MUI sudah mengeluarkan fatwa tentang MLM dengan nama Penjualan Langsung Berjenjang Syariah No 75 Tahun 2009. DSN MUI menetapkan sebagai berikut:

(http://www.e-syariah.com):

1. PenjualanLangsung Berjenjangadalahcara penjualan barang atau jasa melalui jaringan pemasaran yang dilakukan oleh perorangan atau badan usaha kepada sejumlah perorangan atau badan usaha lainnya secara berturut-turut.

2. Barang adalah setiap benda berwujud, baik bergerak maupun tidak bergerak, dapat dihabiskan maupun tidak dapat dihabiskan, yang dapat dimiliki, diperdagangkan, dipakai, dipergunakan, atau dimanfaatkan oleh konsumen.

3. Produk jasa adalah setiap layanan yang berbentuk pekerjaan atau pelayanan untuk dimanfaatkan oleh konsumen.

4. Perusahaan adalah badan usaha yang berbentuk badan hukum yang melakukan kegiatan usaha perdagangan barang dan atau produk jasa dengan sistem penjualan langsung yang terdaftar menurut peraturan perundang-undangan yang berlaku.

5. Konsumen adalah pihak pemakai barang dan atau jasa, dan tidak untuk diperdagangkan. 
6. Komisi adalah imbalan yang diberikan oleh perusahaan kepada mitra usaha atas penjualan yang besaran maupun bentuknya diperhitungkan berdasarkan prestasi kerja nyata, yang terkait langsung dengan volume atau nilai hasil penjualan barang dan atau produk jasa.

7. Bonus adalah tambahan imbalan yang diberikan oleh perusahaan kepada mitra usaha atas penjualan, karena berhasil melampaui target penjualan barang dan atau produk jasa yang ditetapkan perusahaan.

8. Ighra"e adalah daya tari luar biasa yang menyebabkan orang lalai terhadap kewajibannya demi melakukan hal-hal atau transaksi dalam rangka mempereroleh bonus atau komisi yang dijanjikan.

9. Money Game adalah kegiatan penghimpunan dana masyarakat atau penggandaan uang dengan praktik memberikan komisi dan bonus dari hasil perek-rutan/pendaftaran Mitra Usaha yang baru/bergabung kemudian dan bukan dari hasil penjualan produk, atau dari hasil penjualan produk namun produk yang dijual tersebut hanya sebagai kamuflase atau tidak mempunyai mutu/kualitas yang dapat dipertanggung jawabkan.

10. Excessive mark-up adalah batas marjin laba yang ber-lebihan yang dikaitkan dengan hal-hal lain di luar biaya.

11. Member getmember adalah strategi perekrutan keang-gotaan baru PLB yang dilakukan oleh anggota yang telah terdaftar sebelumnya.

12. Mitra usaha/stockist adalah pengecer/retailer yang menjual/memasarkan produk-produk penjualan langsung.

Demikianlah isi dari ketentuan yang telah dibuat oleh DSN MUI. Selanjutnya Praktik Penjualan Langsung Berjenjang Syariah (PLBS) wajib memenuhi ketentuan-ketentuan sebagai berikut:

1. Adanya obyek transaksi riil yang diperjualbelikan berupa barang atau produk jasa;

2. Barang atau produk jasa yang diperdagangkan bukan sesuatu yang diharamkan dan atau yang dipergunakan untuk sesuatu yang haram;

3. Transaksi dalam perdagangan tersebut tidak mengandung unsur gharar, maysir, riba, dharar, dzulm, maksiat;

4. Tidak ada kenaikan harga/biaya yang berlebihan (excessive mark-up), sehingga merugikan konsumen karena tidak sepadan dengan kualitas/manfaat yang diperoleh;

5. Komisi yang diberikan oleh perusahaan kepada anggota baik besaran maupun bentuknya harus berdasarkan pada prestasi kerja nyata yang terkait langsung dengan volume atau nilai hasil penjualan barang atau produk jasa, dan harus menjadi pendapatan utama mitra usaha dalam PLBS;

6. Bonus yang diberikan oleh perusahaan kepada anggota (mitra usaha) harus jelas jumlahnya ketika dilakukan transaksi (akad) sesuai dengan 
target penjualan barang dan atau produk jasa yang ditetapkan oleh perusahaan;

7. Tidak boleh ada komisi atau bonus secara pasif yang diperoleh secara reguler tanpa melakukan pembinaan dan atau penjualan barang dan atau jasa;

8. Pemberian komisi atau bonus oleh perusahaan kepada anggota (mitra usaha) tidak menimbulkan ighra ${ }^{e e}$.

9. Tidak ada eksploitasi dan ketidakadilan dalam pembagian bonus antara anggota pertama dengan anggota berikutnya;

10. Sistem perekrutan keanggotaan, bentuk penghargaan dan acara seremonial yang dilakukan tidak mengandung unsur yang bertentangan dengan aqidah, syariah dan akhlak mulia, seperti syirik, kultus, maksiat dan lain-lain;

11. Setiap mitra usaha yang melakukan perekrutan keanggotaan berkewajiban melakukan pembinaan dan pengawasan kepada anggota yang direkrutnya tersebut;

12. Tidak melakukan kegiatan money game.

Demikianlah isi fatwa DSN-MUI mengenai MLM Syariah yang dikeluarkan oleh Dewan Syariah Nasional pada tahun 2009.

Kehidupan manusia tidak lepas dari peraturan hukum. Patokan-patokan hukum yang mengatur hubungan hak dan kewajiban dalam kehidupan masyarakat atau yang disebut mu'amalah. Tidak dapat dipungkiri bahwa manusia diciptakan oleh Allah SWT dimuka bumi ini untuk menjalankan kewajibannya dan memenuhi kebutuhan hidupnya baik dalam masalah ukhrowi maupun dalam masalam duniawi, tapi uniknya, sampai saat ini belum ada kata pasti atau kesimpulan akhir dari perseteruan tersebut, alias mengambang. Termasuk alasan-alasan yang disodorkan, utamanya oleh pihak penentang MLM. Kesannya hanya sepihak dan tidak solutif. sebab jika ditelisik seakan hanya mengulang apa yang mereka dikemukakan para pendahulu mereka, tidak ada hal yang baru.

Yang penting adalah bagaimana menyikapi perubahan itu, agar mengarah pada keadaan lebih baik. Butuh kewaspadaan dan sikap mawas diri yang tinggi. Jangan sampai muara perubahan bukan kemajuan, tapi malah kemunduran di seluruh sektor kehidupan. Jika ini yang terjadi, dampak nya tidak hanya menimpa pelaku perubahan. Masyarakat luas dan alam sekitarnya akan terkena imbasnya. Baik di kehidupan dunia terlebih akhirat kelak. Sungguh, indikasi keharusanberubah, sudah diberitakan Al-Qur'an, di antaranya firman Allah Subhanahu Wata'ala:

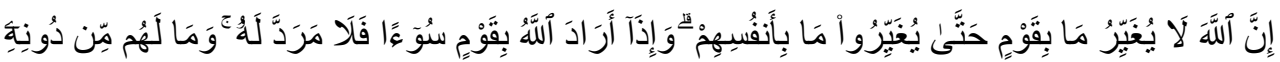

$$
\begin{aligned}
& \text { مِن وَالٍٍ }
\end{aligned}
$$


Artinya:

"Sesungguhnya Allah tidak merubah keadaan sesuatu kaum sehingga mereka merubah keadaan yang ada pada diri mereka sendiri. Dan apabila Allah menghendaki keburukan terhadap sesuatu kaum, maka tak ada yang dapat menolaknya; dan sekali-kali tak ada pelindung bagi mereka selain Dia" (Al-Ro'du: 11).

Menurut kajian fiqh, bisnis adalah termasuk dalam pembahasan muamalah yang terangkum pada bab jual beli. Sebagaimana telah dijelaskan dalam Alquran mengenai jual beli yaitu pada QS. Al-Baqarah: 275

$$
\text { وَأَحَلَّ اللَّهُ الْبِيْعَ وَحَرَّمَ الرِّبَا }
$$

Artinya:

"Padahal Allah telah menghalalkan jual beli dan mengharamkan riba" Sebuah kaidah mukhtabar dalam syari'at mengatakan:

$$
\text { الحكم على الثيء فرع عن تصوره }
$$

\section{“al-hukmu 'ala as-syai-i far'un 'an tashawwurihi”,}

"Vonis hukum tentang sesuatu adalah bagian (hasil) dari pemahaman tentang hakikatnya." Bahwa informasi dan gambar lengkap akan sesuatu merupakan bagian terpenting dalam proses penetapan hukumnya.

Dengan kalimat lain, justifikasi terhadap sesuatu harus berdasarkan pengetahuan yang sempurna dan tidak parsial. Karena hukum yang lahir dari bangunan informasi yang tidak sempurna dapat dipastikan akan pincang, keliru, bahkan dholim. Sungguh, sikap adil dan objektif dalam menimbang sesuatu merupakan keharusan sekaligus kemuliaan bagi seorang muslim, terlebih terkait dengan orang banyak.

Allah Ta'ala mengingatkan kita dalam firman-Nya:

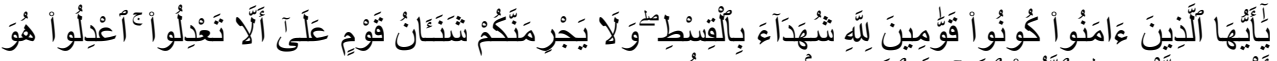

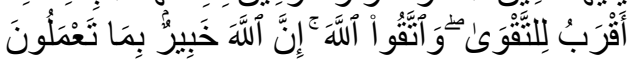

Artinya:

"Hai orang-orang yang beriman, hendaklah kamu jadi orang-orang yang selalu menegakkan (kebenaran) karena Allah, menjadi saksi dengan adil. Dan janganlah sekali-kali kebencianmu terhadap sesuatu kaum, mendorong kamu untuk berlaku tidak adil. Berlaku adillah, karena adil itu lebih dekat dengan takwa. Dan bertakwalah kepada Allah, sesungguhnya Allah Maha Mengetahui apa yang kamu kerjakan”. (Al_Maa'idah: 8). 
Dan sebagaimana dalam kaidah fiqh juga disebutkan bahwa pada dasarnya semua bentuk muamalah boleh dilakukan kecuali ada dalil yang megharamkanya. MLM merupakan satu dari sekian jenis usaha yang belakangan ini banyak menarik perhatian kaum muslimin. Bukan hanya dari kalangan masyarakat awam, tapi juga aktifis pergerakan, bahkan hingga tokoh maysrakat dan agama. Sebabnya, disamping karena MLM dianggap barang baru yang belum ditemukan padanannya pada praktik bisnis zaman dahulu, juga karena beberapa hal dalam aplikasinya yang masih samar bagi sebagian kaum muslimin.

Olehnya, dibutuhkaan analisis syar'i mendalaman serta pengalaman lapangan yaang sifatnya nyata demi menentukan status hukum MLM. Banyak ditemukan dari uraian mereka yang menolak MLM, analisa-analisa yang tidak sesuai dengan faktayang terjadi di lapangan. Dan ini bukan hal kebetulan. Karena kebanyakan mereka hanya bersandar pada berita "katanya" yang bersandar dari mulut ke mulut dan tidak pernah terlibat langsung dalam sistem MLM, melihat fakta-fakta lapangan, serta berinteraksi langsung dengan para pegiat MLM. Untuk tujuan itulah, analisis penelitian ini ditulis. Sebagai orang yang sedang terlibat dan berinteraksi langsung dengan para pegiat MLM, penulis coba memberi kontribusi analisa ilmiah berdasarkan fakta-fakta lapangan. Terutama terkait tujuan yang santer digelontorkan para penentang MLM. Harapannya, semoga dapat meemberi pencerahan serta memperkaya referensi dalam menentukan status hukum syar'i MLM.

Beranjak dari itu, potensi masyarakat yang sudah terbiasa menggunakan teknologi mutakhir, lahirlah gagasan cemerlang dari PT. KLINK NUSANTARA untuk memanfaatkan teknologi yang mutakhir ini dengan mengembangkan bisnisnya dengan cara memasarkannya via Multi Level Marketing atau yang biasa disebut dengan bisnis MLM. Bisnis dengan menggunakan metode Multi Level Marketing ini sangatlah menarik, namun di samping itu kita sebagai ummat muslim harus tau bagaimana hukum bisnis dengan metode MLM ini. Oleh sebab itu Penulis mempunyai gagasan untuk mengakaji bagaimana hukum dari bisni Multi Level Marketing menurut kaca mata Islam. Sehingga lahirlah judul "Bisnis Multi Level Marketing (MLM) Pada PT. K-Link Nusantara Di Tinjau Dari Hukum Bisnis Islam” pada tulisan ini.

\section{METODE}

Metode penelitian adalah cara yang digunakan oleh peneliti untuk mengumpulkan data penelitiannya. Dalam penelitian ini bersifat deskriptif kualitatif sebagai prosedur pemecahan masalah yang diteliti dengan mendeskriptifkan suatu keadaan dilapangan yang menjadi subjek atau objek penelitian dengan cara peneliti mencari sumber data langsung di lapangan. (Rosadi Ruslan, 2004) 
Jenis data yang digunakan dalam penelitian ini adalah data primer. Data yang di peroleh langsung dari subjek penelitian dengan menggunakan alat pengukur atau alat pengambilan data langsung pada subjek sebagai sumber informasi yang dicari. Tehnik analisi data dalam penelitian ini menurut Lexy J. Moleong (2012) proses analisis data dapat dimulai dengan menelaah data yang didapat dari berbagai sumber yakni wawancara, dokumentasi guna memperoleh gambaran yang jelas dalam menyajikan dan menyimpulkan data. Adapun teknik dari analisis data mengacu kepada (Miles dan Huberman, 1992) yaitu sebagai berikut:

1) Reduksi data yaitu merupakan bentuk analisis yang menajamkan, menggolongkan, mengarahkan, membuang yang tidak perlu dan mengorganisasi data dengan cara sedemikian rupa sehingga kesimpulan akhir dapat diambil. Reduksi data meliputi Meringkas data; Mengkode; Menelusurtema; Membuat gugus-gugus

2) Penyajian data adalah kegiatan ketika sekumpulan informasi disusun, sehingga member kemungkinan akan adanya penarikan kesimpulan dan pengambilan tindakan. Bentuk penyajian data kualitatif: a) Teks naratif: berbentuk catatan lapangan, b) Matriks, grafik, jaringan dan bagan. Bentuk bentuk ini menggabungkan informasi yang tersusun dalam suatu bentuk yang padu dan mudah diraih, sehingga memudahkan untuk melihat apa yang sedang terjadi, apakah kesimpulan sudah tepat atau sebaliknya melakukan analisis kembali

3) Penarikan kesimpulan; Upaya penarikan kesimpulan dilakukan peneliti secara terus-menerus dengan berada di lapangan. Dari permulaan pengumpulan data, peneliti kualitatif mulai mencari arti benda-benda, mencatat keteraturan pola-pola (dalam catatan teori), penjelasanpenjelasan, konfigurasi-kunfigurasi yang mungkin, alur sebab-akibat dan proposisi.

\section{HASIL DAN PEMBAHASAN}

Berdasarkan hasil penelitian dari jawaban responden atas pokok permasalahan yang pertama tentang praktik bisnis Multi Level Marketing PT. K-Link Nusantara adalah:

Praktik bisnis Multi Level Marketing pada PT. K-Link Nusantara yaitu dengan cara mejual produk langsung kepada konsumen, menghilangkan kebutuhan grosir yang dilakukan dengan cara one on one, kelompok, online maupun offline, dengan salah satu tujuan untuk mempererat hubungan antar manusia. Sesuai dengan apa yang dikatakan Supriadi Yusuf Boni di dalam bukunya yang berjudul Apa Salah MLM. Beliau mengatakan bahwa : Multi Level Marketing (MLM) atau sistem Networking adalah penjualan secara bertingkat dari distributor mandiri yang memiliki peluang untuk mendapatkan penghasilan dalam 2 cara; 
1) Penjualan produk langsung ke konsumen, Distributor mendapatkan keuntungan atas dasar perbedaan atau selisih antara harga distributor dan harga konsumen.

2) Distributor bisa menerima potongan harga atas dasar jumlahproduk/jasa yang dibeli oleh anggota kelompok bisnis untuk penjualan atau pemakaian, termasuk jumlah penjualan pribadi.

Direct Selling atau penjualan langsung adalah cara memasarkan produk maupun jasa langsung kepada pelanggan, yaitu secara temu muka. Temu muka ini umumnya berlangsung di rumah pelanggan ataupun di rumah teman. Atau tempat lain di luar tempat lokasi pengecer.

Komisi/bonus yang di dapat oleh member atau mitra yang diberikan perusahaan adalah sesuai dengan hasil jerih payah kerja. Semakin semangat dalam memasarkan produk dan jasa maka semakin banyak pula komisi/bonus yang di dapat oleh member/mitra. Praktik ini sesuai dengan landasan teori yang di ambil dari kaidah fiqih yang mengatakan:

Artinya:

"upah adalah sesuai dengan jerih payah atau usaha"

Mitra K-Link wajib mematuhi kode etik perusahaan yang diantaranya adalah Mematuhi undang-undang penjualan langsung, selalu bersikap jujur dan benar, tidak mengkritik atau membuat komentar yang memfitnah orang lain, baik di dalam organisasi anda sendiri atau perusahaan lain, tidak menggunakan cara-cara yang tidak etis ketika melakukan bisnis.

Praktik bisnis Multi Level Marketing pada PT. K-Link Nusantara kurang lebih sudah sama dengan tulisan-tulisan para ahli yang dituangkan dalam buku-buku dan praktiknya yang mengatakan segala sesuatu dalam muamalah itu diperbolehkan sampai ada dalil yang melarangnya. Di dalam praktik bisnis Multi Level Marketing pada PT. K-Link Nusantara menunjukkan bahwa tidak ada satupun praktik yang menunjukkan bahwa praktik itu diarang oleh hukum Islam. Mulai dari praktik dirrect sellingnya, pemasaran dan prekrutannya, sampai pada cara pembagian bonusnya.

Praktik bisnis MLM pada K-Link ini juga selain mengharapkan untung (komisi/bonus) juga sangat menjunjung tinggi hablumminallah dan hablumminannas (ukhuwah islamiyah). Karena menjalin hubungan dengan cara muamalah, menghilangkan kebutuhan grosir dan menjalin hubungan antar manusia dengan cara-cara yang baik sesuai dengan kode etik perusahaan yang sudah ada.

Berdasarkan hasil penelitian dari jawaban responden atas pokok permasalahan yang kedua yaitu tentangkesesuaian praktek bisinis MLM KLink dengan fatwa DSN-MUI No 75/DSN-MUI/VII/2009. Aqad yang dipakai 
adalah aqad al-bai' (jual-beli), member membayar sedangkan perusahaan memberikan barang. Yang kedua aqad yang dipakai antara member dengan perusahaan ketika perusahaan menjual secara online adalah aqad wakalah, artinya member sebagai wakil perusahaan untuk menjual kepada orang lain, bedanya dengan aqad yang pertama adalah member membeli sendiri (aqad albai'), sedangkan aqad yang kedua (wakalah) adalah ketika member menjual kepada konsumen dengan cara dropship atau sistem digital network marketing. Aqad yang ke tiga menggunakan aqad Al-ju'alah. Aqad Al-ju'alah adalah perusahaan menjanjikan suatu ju'al (semacam upah tapi bukan ujroh), upah yang diberikan berdasarkan kinerja. Sesuai dengan isi fatwa DSN-MUI No 75/DSN-MUI/VII/2009 yang mengatakan bahwa:

Akad-akad yang dapat digunakan dalam PLBS adalah:

1) Akad Bai'/Murabahah merujuk kepada substansi Fatwa No. 4/DSNMUI/IV/2000 tentang Murabahah; Fatwa No. 16/DSN-MUI/IX/2000 tentang Diskon dalam Murabahah;

2) Akad Wakalah bil Ujrah merujuk kepada substansi Fatwa No. 52/DSNMUI/III/2006 tentang Wakalah bil Ujrah pada Asuransi dan Reasuransi Syariah;

3) Akad Ju'alah merujuk kepada substansi Fatwa No. 62/DSNMUI/XII/2007 tentang Akad Ju'alah;

4) Akad Ijarah merujuk kepada substansi Fatwa No. 9/DSNMUI/IV/2000 tentang Pembiayaan Ijarah.

5) Akad-akad lain yang sesuai dengan prinsip syariah setelah dikeluarkan fatwa oleh DSN-MUI.

Praktek bisinis MLM K-Link Nusantara sudah banyak yang sesuai dengan isi fatwa DSN-MUI No 75/DSN-MUI/VII/2009. Diantataranya adalah tentang aqad jual-beli yang menggunakan aqad al-bai'/murabahah, aqad wakalah, aqad ju'alah, aqad ujroh. Praktik di dalamnya tidak ada yang termasuk dari unsur yang diharamkan seperti maisir, ghoror, haram, riba, bathil, dzul dan maksiat. Bonus yang diberikan kepada member menggunakan aqad ju'al yaitu bonus/upah yang dihasilkan berdasarkan hasil dari kinerjanya. Sedangkan harganya tidak melambung tinggi melampaui kualitas barang sehingga terbilang sudah sesuai dengan pasaran karena menyesuaikan dengan kuantitas dan kualitas produk.

\section{KESIMPULAN}

Setelah mendeskripsikan pembahasan secara keseluruhan sebagai upaya untuk menjawab pokok masalah, akhirnya peneliti dapat menyimpulkan:

1. Praktik bisnis Multi Level Marketing pada PT. K-Link Nusantara saat ini sudah bisa dikatakan sesuai dengan prinsip dasar agama islam yang mengacu pada Al-Qur'an, Hadits, dan Ijma'. Karena praktik bisnis Multi Level Marketing pada PT. K-Link Nusantara mulai dari praktik dirrect 
sellingnya, pemasaran dan prekrutannya, sampai pada cara pembagian bonus dan harganya sudah mengikuti aturan hukum Islam yang ada. Selain mengharapkan untung (komisi/bonus) juga sangat menjunjung tinggi (ukhuwah islamiyah) sebagai poin lebih dari praktik bisnis Multi Level Marketing pada PT. K-Link Nusantara.

2. Praktik bisnis MLM PT. K-Link Nusantara terhindar dari sesuatu yang diharamkan seperti maisir, ghoror, haram, riba, bathil, dzulm dan maksiat. Aqadnya menggunakan aqad al-bai'/murabahah, aqad wakalah, aqad ju'alah, dan aqad ujroh. Jika semua aqad tersebut disesuaikan dengan isi fatwa DSN-MUI Nomor 75/DSN-MUI/VII/2009 Tentang Pedoman Penjualan Langsung Berjenjang Syariah, maka praktik nya sudah bisa dikatakan sesuai dengan fatwa DSN-MUI Nomor 75/DSNMUI/VII/2009.

\section{DAFTAR PUSTAKA}

\section{Buku}

Agustino, Prospek MLM Syari'ah di Indonesia, Republika, (Jakarta : 15 Pebruari 2002)

Andrias Harefa,10 Kiat Sukses Distributor MLM (Cet. IV; Jakarta: PT. Gramedia, PustakaUtama, 2002)

Departemen Agama RI, Alquran dan Terjemahnya (Jakarta: Sygma Examedia Arkanleema, 2019)

Kuswara, Mengenal MLM Syariah, (Jakarta : Qultum Media, 2005)

Moleong, Lexy J. (2012). Metodologi Penelitian Kualitatif. Bandung : PT Remaja Rosdakarya.

Miles,M.B, Huberman,A.M, dan Saldana,J. 2014.Qualitative Data Analysis, A Methods Sourcebook,Edition 3. USA: Sage Publications. Terjemahan Tjetjep Rohindi Rohidi, UI-Press

Nasution, "Metode Research Penelitian Ilmiah" (Jakarta: BumiAksara, 2003).

Rivai Veithzal, Islamic Marketing, (Jakarta: Gramedia, 2012)

Rosadi Ruslan, "MetodologiPenelitian Public Relation danKomunikasi" (Jakarta: Raja Grafindo, 2004).

Peter J. Cloither, Meraup Uang dengan Multilevel Marketing : Pedoman Praktis Menuju Networking Selling yang Sukses, (Jakarta : Gramedia Pustaka Utama, 1994)

Sayyid Sabiq, Fiqih Sunnah jilid 2,Jakarta, Pena Pundi Aksara, 2006

\section{Website}

APLI, ,Anggota APLI ${ }^{e}$, dalam https://www.apli.or.id/daftar-anggota diakses pada 12 Juli 2020 
DSN-MUI, ,Daftar Perusahaan Penjualan Langsung Berjenjang Syariah', dalam https://dsnmui.or.id/sertifikasi/senarai-perusahaan-bersertifikat// diakses pada tanggal 12 Juli 2020

https://tafsirweb.com/1892-quran-surat-al-maidah-ayat-8.html diakses pada tanggal 12 Juli 2020

https://tafsirweb.com/3971-quran-surat-ar-rad-ayat-11.html diakses pada 12 Juli 2020

(http://www.e-syariah.com) diakses pada 12 Juli 2020 